\title{
PENGAJARAN PENDIDIKAN AGAMA ISLAM DENGAN MODEL E-LEARNING PADA MASA PANDEMI COVID-19
}

\author{
Mohammad Ali Mortadlo \\ Universitas Hasyim Asy'ari Tebuireng Jombang \\ E-mail: ali@smpningoro.sch.id \\ Asriana Kibtiyah \\ Universitas Hasyim Asy'ari Tebuireng Jombang \\ E-mail: alc.indonesia@gmail.com
}

\begin{tabular}{|c|c|c|}
\hline Received & Revised & Accepted \\
\hline 4 July $\mathbf{2 0 2 1}$ & 2 Agustus 2021 & 20 September 2021 \\
\hline
\end{tabular}

\section{TEACHING OF ISLAMIC RELIGIOUS EDUCATION WITH E-EARNING MODEL DURING THE COVID-19 PANDEMIC}

\begin{abstract}
The COVID-19 pandemic has become a fairly vicious epidemic because it attacks all countries in the world. To anticipate and reduce the spread of the virus, the world of education uses E-Learning as a shortcut to stay safe and reduce the spread of COVID-19. Researchers are interested in knowing PAI learning with the E-Learning model during the COVID-19 emergency at SMP Negeri 1 Ngoro. There are 3 focuses in this research, namely. 1) Implementation of the E-Learning teaching model in PII subjects, 2) PAI teacher innovation in E-Learning learning, 3) Supporting and inhibiting factors of PAI learning in the ELearning model. This type of research is qualitative research. With a qualitative approach, explanation aims to develop PAI teaching theory and explain changes in phenomena that occur with the influence of influencing factors. From the results of the study, it can be seen that: first, SMP Negeri 1 Ngoro applies an E-Learning learning model, namely the Learning Management System (LMS) which uses a google suite account facility in which there is a google classroom application that functions as a medium for sending and assessing assignments as well as interactions in class. In cyberspace, the Google Form is used as an assessment tool in the form of questions, both multiple choice and description questions, and WhatsApp as a communication application for learning activities. Second, PAI teachers innovate in PAI learning, including using blended learning by combining online and offline activities and hybrid learning, a combination of Synchronous and Asynchronous. Third, there are several inhibiting factors including: 1) signal interference, 2) not having an ideal device, 3) students who are still clueless and need learning assistance, 4) lack of a sense of independence and responsibility in learning. Supporting factors 1) quota assistance from the government, 2) google suite facilities with unlimited storage systems, 3) school internet area with a capacity of 100 megabytes
\end{abstract}

Keywords: teaching, Islamic religious education, and E-Learning model. 


\begin{abstract}
Abstrak
Pandemi COVID-19 menjadi wabah yang cukup ganas karena menyerang ke seluruh negara didunia. Untuk mengantisipasi dan mengurangi penyebaran virus, dunia pendidikan menggunakan ELearning sebagai jalan pintas agar tetap aman dan mengurangi persebaran COVID-19. Peneliti tertarik untuk mengetahui pembelajaran PAI dengan model E-Learning pada masa darurat COVID-19 SMP Negeri 1 Ngoro. Ada 3 fokus dalam penelitian ini, yaitu. 1) Implementasi model pengajaran E-Learning dalam mata pelajaran PAI, 2) Inovasi guru PAI dalam pembelajaran E-Learning, 3) Faktor pendukung dan penghambat pembelajaran PAI dalam model E-Learning.

Jenis penelitian ini adalah penelitian kualitatif. Dengan pendekatan kualitatif ekplanasi bertujuan untuk mengembangkan teori pengajaran PAI dan menjelaskan perubahan fenomena yang tejadi dengan dipengaruhi faktor-faktor yang mempengaruhi. Dari hasil penelitian dapat diketahui bahwa: pertama, SMP Negeri 1 Ngoro menerapkan model belajar E-Learning yaitu Learning Management System (LMS) yang menggunakan fasilitas akun google suite yang di dalamnya terdapat aplikasi google classroom berfungsi sebagai media mengirim dan menilai tugas juga interaksi dalam kelas maya, google form digunakan sebagai alat penilaian yang berbentuk soal-soal baik pilihan ganda maupun soal uraian serta whatsapp sebagai aplikasi komunikasi aktivitas pembelajaran. Kedua, pengajar PAI melakukan inovasi pada pembelajaran PAI diantaranya menggunakan blended learning dengan cara memadukan antara kegiatan daring dengan luring dan hybrid learning perpaduan Synchronous dan Asynchronous. Ketiga, terdapat beberapa faktor penghambat diantaranya: 1) ganguan sinyal, 2) tidak memiliki perangkat yang ideal, 3) peserta didik yang masih gaptek dan butuh pendampingan belajar, 4) kurangnya rasa kemandirian dan tanggung jawab dalam belajar. Faktor pendukung 1) adanya bantuan kuota dari pemerintah, 2) adanya fasilitas google suite dengan sistem penyimpanan yang unlimited, 3) internet area di sekolah dengan kapasitas 100 megabite
\end{abstract}

Kata Kunci: pengajaran, pendidikan Agama Islam, dan model E-Learning

\title{
Pendahuluan
}

Pendidikan Agama Islam (PAI) memegang peranan penting dalam sistem pendidikan di Indonesia yang didasarkan ayat ke-1 Pancasila yaitu Ketuhanan Yang Maha Esa. Dengan begitu maka para pengajar PAI mempunyai tanggung jawab yang besar akan perkembangan dan pertumbuhan peserta didiknya. Sehingga sudah sewajarnya pengajar PAI menggunakan E-Learning sebagai media ajar untuk meningkatkan proses juga mencegah penularan COVID-19. Dalam tiap pembelajaran harus meliputi 3 aspek yaitu: kognitif, afektif dan psikomotorik. Oleh karena itu pengajar PAI kiranya dapat pengembangkan model E-Learning untuk pembelaharan dengan memanfaatkan kemajuan teknologi secara maksimal. Senada dengan hal itu E-Learning sebagai media elektronik dapat membawa dampak perubahan pada proses pembelajaran. Baik berupa Interaksi antara pengajar dan peserta didik, dapat menggunakan media elektronik sebagai perantara sehingga suasana proses pembelajaran menjadi lebih menarik, visual dan interaktif. ${ }^{1}$

Terdapat beberapa dalil yang menjadi rujukan para pengajar PAI sebagai landasan untuk melaksankan model pengajaran jarak jauh. Hal itu dilaksanakan sebagai wujud iman dalam ajaran-ajaran Islam juga sebagai kepedulian dalam berkehidupan di dunia. berikut ini 2 dalil yang menjadi landasan pengajra PAI dalam melaksanakan model E-learning pada masa pandemi COVID-19.

Diriwayat dalam beberapa hadist anjuran agar mencegah penjebaran virus, wabah atau tha'un sebagaiman dijelaskan dan hadist riwayat Bukhari dan Muslim, bahwa

${ }^{1}$ Abusiri, "Implementasi E-Learning Dalam Upaya Meningkatkan Kreativitas Dosen Dan Mahasiswa Di Stai Alhikmah Jakarta," Hikmah XV (2019): 83. 
Rasulullah SAW. bersabda, “Tha'un (wabah penyakit menular) adalah suatu peringatan dari Allah Subhanahu Wa Ta'ala untuk menguji hamba-hamba-Nya dari kalangan manusia. Maka apabila kamu mendengar penyakit itu berjangkit di suatu negeri, janganlah kamu masuk ke negeri itu. Dan apabila wabah itu berjangkit di negeri tempat kamu berada, jangan pula kamu lari daripadanya." (HR Bukhari dan Muslim dari Usamah bin Zaid).

Ada juga hadis yang diriwayakan juga oleh Bukhari dan Muslim bahwa Nabi SAW bersabda: "Janganlah yang sakit dicampurbaurkan dengan yang sehat." (HR Bukhari dan Muslim dari Abu Hurairah)

Dari dalil tesebut dapat kita pahami bahwa Islam sangat menganjurkan dalam menjaga kesehatan saat terjadi wabah khususnya wabah COVID-19. Oleh karena dengan segala daya dan upaya pengajar PAI menggunakan pengajaran model ELearning dalam kondisi darurat ini.

Surat Edaran Nomor 4 Tahun 2020 tentang Pelaksanaan Kebijakan Pendidikan dalam Masa Darurat Penyebaran Corona Virus Disease (Covid-19) yang diterbitkan oleh Menteri Pendidikan dan Kebudayaan Republik Indonesia. Dimana surat edaran ini menekankan bahwa proses pembelajaran dilakukan dengan menggunakan media daring (online). Artinya, proses belajar mengajar bagi peserta didik untuk sementara waktu dilakukan di rumah. Sekalipun demikian, peran guru sebagai pendidik tetap dilaksanakan dengan memanfaatkan media pembelajaran yang ada.

Kemudian pada 15 Maret 2020 presiden dalam konferensi persnya memerintahkan agar kerja, belajar dan ibadah dilaksanakan di rumah. Langkah itu diambil agar kegiatan belajar dan pembelajaran tetap memberikan jaminan keselamatan dan rasa aman serta memperhatikan prosedur kesehatan untuk mencegah penyebaran COVID-19. Gubenur Jawa Timur juga menerbitkan surat edaran no: 420/1780/101.1/2020 tentang Peningkatan Kewaspadaan terhadap Corona Virus Disease (COVID-19) di Jawa Timur yaitu pertanggal 16 Maret 2020 sampai 29 Maret 2020 kegiatan belajar di sekolah dipindahkan ke rumah. ${ }^{2}$

Sekolah di kabupaten Jombang mulai menerapkan belajar dari rumah sesuai edaran Bupati Nomor: 420/2137/415.16/2020 yaitu semua satuan pendidikan di kabupaten Jombang mulai dari PAUD, TK, SD, SMP, SMA, PKBM, serta LPK negeri maupun swasta supaya mengalihkan sementara kegiatan belajar ke rumah. ${ }^{3}$ Dengan begitu setiap instansi tersebut mulai mengadakan pembelajaran melalui smartphone dan pada umumnya menggunakan aplikasi whatsapp, hal itu dipakai untuk memberikan tugas pada tiap peserta didik untuk tetap melakukan aktivitas belajar di rumah.

Hanum dalam risetnya menyebutkan bahwa kegiatan pembelajaran daring belum begitu efektif atau optimal. Hal ini disebabkan banyaknya kendala yang dialami seperti kekurangan sarana dan prasarana layaknya gawai dan jaringan internet serta

\footnotetext{
2“Surat Edaran Gubernur Jawa Timur Tanggal 15 Maret 2020 Perihal Peningkatan Kewaspadaan Corona Virus Disease 2019 (COVID-19) - Universitas Islam Negeri Sunan Ampel Surabaya," diakses 1 Juni 2021, https://w3.uinsby.ac.id/surat-edaran-gubernur-jawa-timur-tanggal-15-maret-2020-perihal-peningkatankewaspadaan-corona-virus-disease-2019-covid-19/.

${ }^{3}$ Edaran bupati jombang nomor :80o/1058/415.41/2020 tantang penyesuaian sistem kerja dalam upaya pencegahan dampak COVID-19 di lingkup pemkab jombang
} 
kurangnya tingkat literasi media digital masyarakat. ${ }^{4}$ Namun tidak dapat dipungkiri suatu wabah yang secara tiba-tiba menyerang dan mengubah secara drastis seluruh sistem baik pemerintahan, perekonomian, serta pendidikan. Bidang pendidikan turut andil dalam perubahan proses pembelajaran yang biasanya menggunakan model konvensional dengan bertatap muka, kini beralih menjadi model pembelajaran jarak jauh (PJJ). Hal itu diharapkan mampu menekan penyebaran COVID-19.

Pembelajaran jarak jauh dapat dilakukan dengan menggunakan media elektronik seperti gawai atau komputer. Sehingga biasa disebut juga dengan Elektronik Learning (E-Learning). E-Learning dirasa mampu mengoptimalkan pendidikan ketika dalam COVID-19. Dalam pelaksanaanya model E-Learning menggunakan teknologi internet dalam kegiatan pembelajaran sehingga kegiatan pembelajaran mampu diselenggarakan secara luas, cepat dan tanpa bertatap muka. E-learning juga dapat menjadi salah satu solusi dibidang pendidikan. Yaitu tetap menjaga jarak dan menghindari kerumunan.

Dalam model pengajaran E-Learning, pada umumnya guru memberikan aktivitas belajar berupa penugasan yang melalui aplikasi whatsapp maupun google classroom baik menulis, praktik maupun soal ulangan. Namun tak jarang ada beberapa siswa yang tidak mengerjakan tugas yang diberikan dengan berbagai kondisi dan alasan seperti sinyal yang tidak mendukung juga kehabisan kuota internet.

Mengutip dari pendapat Bruce bahwa ada begitu banyak model pembelajaran, sebagian ada yang hanya bisa diterapkan untuk satu atau dua tujuan, sebagian lagi ada yang bisa diterapkan untuk tujuan yang lebih besar, dan sebagian lain ada yang benar-benar untuk tujuan tertentu. ${ }^{5}$ Dengan kata lain dalam pemahaman kita tentang pembelajaran tidak ada satupun model pengajaranyang bisa menggantikan model lain. Maupun model tersebut yang paling unggul, yang ada hanyalah model yang tepat sesuai dengan materi dan tujuan yang ingin dicapai hal ini dapat dipahami bahwa dalam model E-Learning membutuhkan penyesuaian atau inovasi dalam penerapannya dalam proses pembelajaran.

Model pengajaran E-Learning mempunyai kelebihan dibanding dengan model konvensional karena tak adanya keterbatasan ruang dan waktu. ${ }^{6}$ Dengan kata lain siswa dapat mengerjakan tugas dimana saja dan kapan saja. Namun Huzaimah menyatakan dalam risetnya bahwa terdapat beberapa hambatan yang dialami siswa pada saat pembelajaran dalam jaringan (daring) dan guru dihimbau untuk lebih kreatif atau berinovasi supaya tidak muncul kejenuhan dan kemalasan dalam belajar. $^{7}$

SMPN 1 Ngoro sudah mengunakan model pengajaran E-Learning seperti google classroom yang digunakan untuk memberikan tugas, menyimpan nilai, absensi dan

\footnotetext{
${ }^{4}$ Fauziah Hanum dan Heylen Amildha Yanuarita, "Efektivitas Pembelajaran Dalam Jaringan (Daring) Selama Pandemi Covid-19 Di Kabupaten Jombang” 4, no. 4 (2020): 6.

${ }^{5}$ Bruce Joyce, Models of Teaching edisi 8 : Model-Model Pengajaran, 8 ed. (Yogyakarta: Pustaka Pelajar, 2016).

${ }^{6}$ Subakdo Eko Yulianto, "Pengaruh Persepsi Kemudahan Dan Persepsi Kemanfaatan Terhadap Pemanfaatan E-Learning Dengan Model Tam Di Smk Muhammadiyah 3 Yogyakarta,” t.t., 46.

${ }^{7}$ Pipip Zulfa Huzaimah dan Risma Amelia, "Hambatan yang Dialami Siswa Dalam Pembelajaran Daring Matematika Pada Masa Pandemi COVID-19," Jurnal Cendekia.Vol. o5, no. o1 (2021): 9.
} 
materi. Namun dalam perjalanannya beberapa siswa mengalami kendala diantaranya jaringan internet ataupun gawai yang kurang optimal dalam proses pembelajaran sehingga sering terhambat seperti halnya kehilangan akun akibatnya beberapa siswa tertinggal materi pelajaran karena tidak mengikuti kegiatan dalam google classroom. Dari masalah itu kemudian sekolah mengusulkan kepada perusahaan google supaya diberikan fasilitas google suite. Saat ini SMPN 1 Ngoro sudah memiliki Google Suite yangmempunyai keunggulan dimana akun para siswa tersimpan pada data server sekolah dan tidak perlu ganti akun ketika gawai mengalami masalah. SMPN 1 Ngoro termasuk sekolah favorit, pada tahun 2012 sebagai Rintisan Sekolah Bertaraf Internasional (RSBI) dan sekarang masih menjadi sekolah imbas atau yang menjadi percontohan untuk sekolah sederajat yang berada di lingkungan Kabupaten Jombang. Pada Tahun 2019 SMPN 1 Ngoro termasuk dalam sekolah Adiwiyata.

Penerapan model pengajaran E-Learning di SMPN 1 Ngoro bisa jadi menjadi salah satu faktor keberhasilan dalam meraih berbagai prestasi selama ini. Dari pemaparan konteks penelitian ini, penulis ingin melihat dan mengkaji secara mendalam penerapan model E-Learning dalam pengajaran PAI selama masa pandemi COVID19.

\section{Hasil dan Pembahasan}

\section{Perkembangan E-Learning dalam Pembelajaran}

E-Learning banyak digunakan dalam beberapa tahun ini, dikarenakan adanya COVID-19. Para pengajar secara serentak harus menggunakan alat elektronik untuk tetap membuat aktivitas belajar bisa tetap berjalan sebagaimana yang telah direncanakan dan menjadi kurikulum sekolah. Alat elektronik yang paling sering digunakan yaitu gawai atau smartphone atau handphone tentunya dengan bantuan jaringan internet. Ali Sadikin dkk, menyebutkan bahwa pembelajaran daring mampu mengurangi persebaran COVID-19 karena peserta didik tetap bisa melakukan kegiatan pembelajaran dari manapun dan kapanpun. ${ }^{8}$

E- learning diambil dari huruf E kependekan dari kata Elektronic dan Learning yang berasal dari bahasa Inggris yang mempunyai arti pembelajaran elektronik. E learning atau dalam jaringan (daring) mulai dikenalkan pada dunia sejak tahun 1960 di University of Illinois dan diberi nama Programmed Logic for Automated Teaching Operations (PLATO dengan program $C_{1}$ diterimanya CBT ole standar yang dikelua

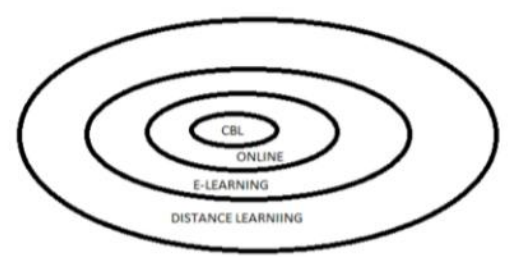
serkembang pada tahun 1990 Tahun 1994, Seiring dengan Learning Management System) -BT Commettee).

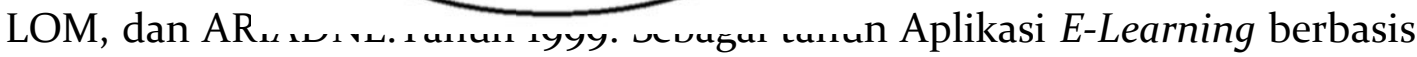
Web. ${ }^{9}$

${ }^{8}$ Ali Sadikin dan Afreni Hamidah, "Pembelajaran Daring di Tengah Wabah Covid-19," BIODIK 6, no. 2 (30 Juni 2020): 109-19, https://doi.org/10.22437/bio.v6i2.9759.

${ }^{9}$ Lidia Simanihuruk dkk., E-Learning: Implementasi, Strategi dan Inovasinya, 1 ed. (Medan: Yayasan Kita Menulis, 2019), 6. 

seluruh bentuk pembelajaran (pendidikan dan pelatihan) jarak jauh, baik yang berbasis korespondensi (modul tercetak) maupun yang berbasis teknologi. Kedua, ELearning, merupakan bentuk pembelajaran jarak jauh yang menggunakan teknologi (synchronous dan asynchronous). Ketiga, On line learning, memanfaatkan teknologi internet yang dikenal dengan web based learning. Keempat, Computer based learning, memanfaatkan komputer sebagai terminal akses ke proses belajar (CD-ROM learning) DistancE-Learning, E-Learning Online CBL

Dalam perkembangannya E-Learning menggunakan 2 metode yaitu, synchronous dan asynchronous. Synchronous memiliki arti sinkron, yaitu dimana komunikasi dalam proses pembelajaran antara pengajar dan peserta didik dilakukan secara realtime atau pada saat yang sama. ${ }^{10}$ Seperti Zoom meeting, Google Meet dan Live chat Whatsapp. Asynchronous interactivity is the third major distance education approach. ${ }^{11}$ Memiliki arti Asinkron atau tidak pada waktu yang bersamaan" dengan cara menggabungkan teknik belajar mandiri dengan interaktivitas asinkron menciptakan lingkungan dimana peserta didik dapat mengakses sumber belajar jarak jauh secara asinkron menggunakan peralatan yang relatif murah untuk belajar di rumah, di tempat kerja atau dimana pun pilihan mereka. Pembelajaran jarak jauh dapat meminta sumber daya dinamis seperti siswa lain, tanpa guru atau instruktur, atau sumber daya yang lebih statis seperti tugas, catatan kursus, atau perpustakaan.Sumber daya digital tambahan dapat mencakup database, spreadsheet, atau bahkan yang dihasilkan simulasi perangkat lunak. ${ }^{12}$

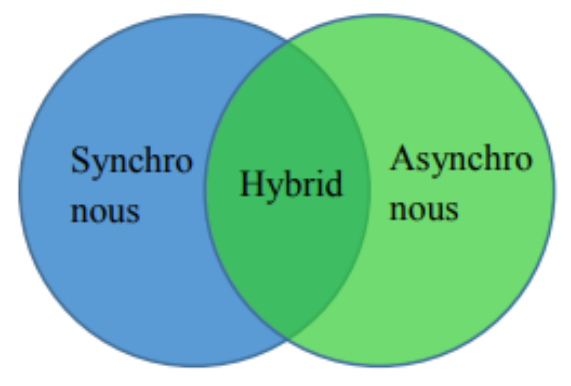

\section{Tahapan Pelajaran E-Learning}

Figure 2 Kombinasi Tipe Komunikasi dalam E-Learning

Tahapan pembelajaran dengan E-Learning menggunakan komunikasi hybrid dapat dijelaskan. Pertama, tahapan pra pembelajaran yang meliputi; (1) pengajar membuat

\footnotetext{
${ }^{10}$ Muhammad Hanif Fahmi, “Komunikasi Synchronous Dan Asynchronous Dalam E-Learning Pada Masa Pandemic Covid-19," Jurnal Nomosleca 6, no. 2 (30 Oktober 2020), https://doi.org/10.26905/nomosleca.v6i2.4947.

${ }^{11}$ Frank Mayadas, "Asynchronous Learning Networks: A Sloan Foundation Perspective," Online Learning 1, no. 1 (19 Maret 2019), https://doi.org/10.24059/olj.vii1.1941.

${ }^{12}$ Fahmi, "komunikasi synchronous dan asynchronous dalam e-learning pada masa pandemic covid-19.", Jurnal Nomesleca, Vol. 6, No. 2, (Malang: Fak. Ilmu Sosial Politik Universitas Merdeka)
} 
grup whatsapp dan mengundang seluruh peserta didik ke grup whatsapp, (2) pengajar menyiapkan rencana pembelajaran dalam satu semester, (3) pengajar mengunggah materi (bahan bacaan atau powerpoint) ke Google Classroom, (4) pengajar membuat rekaman video materi pembelajaran yang diunggah ke youtube, dan (5) pengajar menyiapkan latihan soal menggunakan aplikasi Quizziz atau Google Form

Selanjutnya adalah tahapan pelaksanaan pembelajaran yang meliputi; (1) pengajar menyampaikan prosedur pembelajaran melalui grup whatsapp (Asynchronous), (2) pengajar mengarahkan peserta didik untuk mengunduh dan mempelajari materi yang ada di google form atau youtube (Asynchronous), dan (3) pembelajaran dan peserta didik melakukan komunikasi synchronous dalambentuk pertemuan virtual melalui grup whatsapp (live chat) sesuai dengan jadwal kegiatan tatap muka. Poin ketiga ini bisa dilakukan dengan kegiatan antara lain, (a) pengajar mendeskripsikan materi pembelajaran menggunakan pesan teks atau pesan suara, (b) diskusi interaktif materi pembelajaran melalui pesan teks, (c) pengajar membagikan tautan presensi google form yang harus diisi peserta didik selama proses pembelajaran berlangsung, dan (d) diakhir pertemuan, pengajar membagikan link latihan soal menggunakan quizziz atau fitur kuis pada google classroom.

Selain itu, juga dalam satu semester melakukan tatap muka virtual sebanyak 3-4 (empat) kali menggunakan Zoom Meeting, Google Meet atau Microsoft Team. Kegiatan pembelajaran yang dilakukan menggunakan live chat whatsapp (Synchronous). Peserta didik mengerjakan latihan soal pada quizziz atau google classroom serta mempelajari materi untuk pertemuan berikutnya.

Clark \& Mayer menuturkan terdapat 5 karakter E-Learning yang harus tercakup dalam pengajaran di antaranya, E-Learning harus relevan antara konten dengan tujuan pembelajaran. Selain itu, metode yang digunakan yaitu intruksional seperti penyajian contoh dan latihan soal. E-Learning juga Menggunakan konten yang menarik seperti elemen kata-kata atau gambar. Ia juga Dapat menyesuaikan pembelajaran berpusat pada pengajar (synchronous E-Learning) atau pembelajaran mandiri (asynchronous E-Learning) dan mengkontruksi kemampuan diri maupun kelompok dalam pemahaman dan ketrampilan yang dimaksud dalam tujuan belajar ${ }^{13}$

\section{Karakteristik E-Learning}

Menurut Rusman E-Learning memiliki karakteristik, antara lain (a) interactivity (interaktivitas), (b) independency (kemandirian), (c) accessibility (aksesibilitas), (d) enrichment (pengayaan). ${ }^{14}$ Sedangkan karakteristik E-Learning, antara lain, (1) memanfaatkan jasa teknologi elektronik, di mana guru dan siswa, siswa dan sesama siswa atau guru dan sesama guru dapat berkomunikasi dengan relatif mudah dengan tanpa dibatasi oleh hal-hal yang protokoler, (2) memanfaatkan keunggulan komputer (digital media dan computer networks), (3) menggunakan bahan ajar bersifat mandiri (self learning materials) disimpan di komputer sehingga dapat

\footnotetext{
${ }^{13}$ Ruth Colvin Clark dan Richard E Mayer, E-Learning and the Science of Instruction (United States of America: Pfeiffer, 2011), 33.

${ }^{14}$ Rusman., Kurniawan, D., \& Riyana, C., Pembelajaran berbasis teknologi informasi dan komunikasi, mengembangkan profesionalitas guru (Jakarta: PT. Raja Grafindo, 2011), 45.
} 
diakses oleh guru dan siswa kapan saja dan di mana saja bila yang bersangkutan memerlukannya, dan (4) memanfaatkan jadwal pembelajaran, kurikulum, hasil kemajuan belajar dan hal-hal yang berkaitan dengan administrasi pendidikan dapat dilihat setiap saat di komputer.

Untuk mencapai karakteristik pembelajaran E-Learning sangat dibutuhkan kemahiran dalam kompetensi teknologi informasi dan komunikasi (TIK). Berikut ini gambaran alur tingkat kemampuan guru dalam penguasaan TIK.

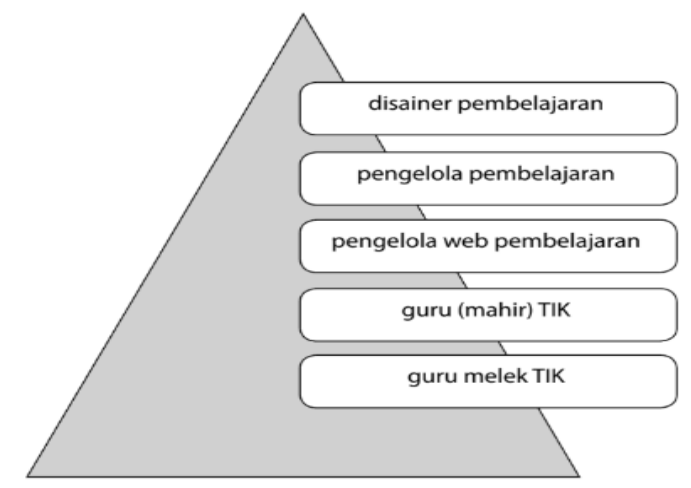

Figure 3 Topografi keterampilan guru dalam bidang TIK $^{15}$

Gambar diatas dapat diketahui bahwa terdapat beberapa jenjang kemampuan guru dalam bidang TIK yang erat kaitannya dengan model pengajaran E-Learning. Mulai dari yang paling dasar hingga sampai puncak dapat dijabarkan sebagi berikut. Pertama, guru melek TIK, maksudnya guru sekedar tahu beberapa pengetahuan tentang TIK dan mampu mengaplikasikan TIK dalam kehidupan sehari-hari. Kedua, guru Mahir TIK, dapat diartikan bahwa guru tahu banyak pengetahuan tentang TIK tidak hanya sekedar dapat menggunkan namun dapat membuat variasi yang lebih canggih dari pada guru melek TIK. Ketiga, guru mampu pengelola web pembelajaran,pada jenjang ini guru sudah mampu untuk mengelola web baik dengan program-program penunjang web itu sendiri. Keempat, guru Pengelola Pembelajaran, pada taham ini ini guru mampu menambahkan variasi dan fitur-fitur yang menarik dan web pembelajaran. Kelima, guru sebagai desainer pembelajaran, pada puncak ini guru mampung menggunakan, mengelola dan membuat web pembelajaran.

\section{Ketarampilan Guru PAI Menghadapi E-Learning}

Dari penjabaran di atas maka keterampilan guru PAI sewajarnya mampu menguasai bidang TIK yang dibutuhkan dalam inovasi pengajaran PAI. Pengajar harus mampu menguasai materi ajar juga karakteristik siswa dalam menerima pengajaran dalam model E-Learning. Bahan pengajaran PAI berbasis E-Learning merupakan materi pembelajaran yang dibuat, diterapkan dan dimanfaatkan melalui media internet. Bahan materi pembelajaran ini memiliki ciri-ciri menampilkan multimedia, mengolah, menyajikan serta menyimpan informasi, dan adanya hyperlink (pertautan). Selain itu, bahan pembelajarannya juga memiliki beberapa unsur,

${ }^{15}$ Dewi Salma Prawiradilaga, Mozaik Teknologi Pendidikan: E-Learning (Jakarta: Kencana, 2016), 4. 
diantaranya yaitu, mencakup tujuan, sasaran, uraian materi, sistematika sajian, instruksi belajar, dan evaluasi ${ }^{16}$

Pengajar PAI selayaknya mampu menyesuaikan bahan ajar dengan aplikasi atau metode ajar yang akan digunakan. Contoh: dalam menyampaikan bahan ajar berupa tarikh atau sejarah Islam. Pengajar PAI dapat menyajikan video pembelajaran yang menarik baik berupa sejarah Islam atau sebuah animasi gambar sehingga menimbulkan motivasi belajar pada peserta didik.

Penyusunan program sistem pembelajaran berbasis E-Learning dapat dilakika dalam beberpapa tahap. Pertama, tahap perencanaan awal, yaitu mengidentifikasi tujuan, kebutuhan dan masalah yang muncul dalam pembelajaran, analisis karakteristik peserta didik yang akan menggunakan modle E-Learning, dan melajari materi yang akan dikembangkan. Pada tahap ini, penyelenggara pembelajaran ini, juga harus mempertimbangkan strategi pembelajaran.

Paling pertama, yaitu menyiapkan materi. Guru harus menguasai materi dan metodologi pembelajaran, prosedur pengembangan media, teknik pemograman computer, dan keterbatasan komputer. Selanjutnya pendidik mendesain paket program pembelajaran. Dalam hal ini yang perlu diperhatikan adalah memperkenalkan materi baru untuk melengkapi atau menguatkan pembelajaran yang telah berlangsung dengan media lain. Pendidik, setelah itu, harus memvalidasi paket program pembelajaran. Memvalidasi paket program membuktikan validitasnya secara empiris lewat uji lapangan pada paket program yang dikembangkan. Paket program diuji cobakan dengan memilih sampel yang representatif.

Sementara itu, Moesfajar Hadi Iswidodo, S.Pd. selaku kepala Sekolah SMPN 1 Ngoro Jombang menjelaskan situasi pembelajaran dengan model E-Learning di sekolah yang ia pimpin pada masa darurat COVID-19, bahwa pada masa darurat COVID-19, SMPN 1 Ngoro mengimplementasikan model belajar E-Learning. berikut penjelasan beliau berkaitan proses pembelajara pada masa darurat COVID-19, saat peneliti melakukan wawancara di ruang Kepala Sekolah .

Di SMPN 1 Ngoro beberapa mata pelajaran sudah melaksanakan pembelajaran E-Learning. Di antaranya yaitu mata pelajaran Pendidikan Agama Islam karena menyesuaikan dengan kondisi saat ini untuk meminimalisia kerumunan. ${ }^{17}$

Senada dengan hal itu Kepala Urusan Kurikulum, Anang Andik Herwanto, S.Pd. mengklarifikasi sebagai berikut:

SMPN 1 Ngoro sudah menggunakan model E-Learning yaitu learning management system (LMS). Menggunaka akun google suite yang di dalamnya sudah terdapat beberapa learning management System di antaranya google classroom, google form, google meet dalan lain sebagainya. ${ }^{18}$

\footnotetext{
${ }^{16}$ Dalam Proses Pembelajaran pada Program Studi PAI Universitas Islam Negeri Raden Fatah Palembang. Hayula: Indonesian Journal of Multidisciplinary Islamic Studies, 3(1), $105^{-120 .}$ https://doi.org/10.21009/003.1.06

${ }^{17}$ Moesfajar Hadi Iswidodo, Wawancara Pribadi, oo1, 17 Maret 2021

${ }^{18}$ Anang Andik Herwanto, Wawancara Pribadi, oo1, 18 Maret 2021
} 
Di lain tempat ketika peneliti berada di ruang Tata Usaha bertemu dengan Kepala Urusan Sarana dan Prasana yaitu Bapak Wahyudi, S.Pd. M.Si beliau menyatakan kegiatan pembelajaran pada masa darurat menggunakan model belajar E-Learning.

Pada masa pandemi covid-19 SMPN 1 Ngoro menggunakan model belajar E-Learning. Karena wabah pandemi ini kira harus mementingkan kepentingan bersama baik kepada para guru, beserta didik juga masyarakat supaya unutuk menunduk kegiatasa yang dapat menyebarkan covid-19 lebih luas. ${ }^{19}$

Data tersebut sebagai acuan para guru untuk melaksanakan E-Learning dalam proses pembelajaran PAI. Selanjutnya dalam rangka merealisasikan pembelajaran ELearning. Peneliti melakukan wawancara dengan guru PAI kelas VII yaitu Moh. Fajar Husain, S, Pd. Yang menjelasnya situasi saat itu dalam proses pelaksanaan pembelajaran dengan kurikulum darurat:

Pembelajaran pada masa COVID-19 mengalami banyak hambatan sebenarnya melalui online dapat mencakup semua pihak, namun untuk Indonesia sendiri belum cukup optimal perihal hardware atau perangkatnya masih belum memadai jangankan yang di pelosok yang di kota saja tidak semua peserta didik memiliki device atau alat elektronik misal smartphone atau laptop. Seumpanya guru melakukan pembeajaran dengan membagikan link atau zoom, google meet, peserta didik akan sangat keksusahan karena ketiadaan perangkat yang memadai jadi masih banyak mengalami hambatan. ${ }^{20}$

Selanjutnya peneliti melakukan wawancara dengan guru PAI kelas VIII yaitu Ibu Ima Rahmatul Laiali, M.Pd, beliau menjelaskan situasi pembelajaran pada masa darurat sebagai berikut:

Pembelajaran pada masa pandemi COVID-19 ini, cukup sulit dilaksakan dengan sempurna menurut saya pribadi. Karena pada masa ini kita tidak memungkinkan untuk melakukan pembelajaran tatap muka. Meskipun pembelajaran bisa dilakukan secara online tapi tidak semua peserta didik dapat memahami materi dengan mudah. Banyak peserta didik yang masih membutuhkan penjelasan lebih detail terkait dengan materi yang diajarkan. $^{21}$

Senada dengan hal itu Ibu Sholihatul Ummah, S. Ag. Sebagai guru PAI kelas IX juga mengungkapkan pendapatnya tentang situasi pembelajaran pada masa darurat. Saat itu dilakukan wawan cara para ruang guru. Berikut pernyataan beliau:

Menurut saya pembelajaran pada masa COVID-19 hasilnya kurang maksimal dan kurang efektif Pembelajran Jarak Jauh ( PJJ). Karena kami para guru kurang bisa memantau aktivitas peserta didik hanya mampu menghimbau memlau smartphone yaitu whatsapp. ${ }^{22}$

Dengan situasi pebelajaran yang berlangsung saat itu maka para guru PAI Menggunakan PJJ model E-Learning sebagai akomodasi pembelajaran yang tidak

\footnotetext{
${ }^{19}$ Wahyudi, wawancara pribadi, oo1, 19 Maret 2021.

${ }^{20}$ Muhammad Fajar Husein, Wawancara Pribadi, oo1, 21 Maret 2021

${ }^{21}$ Ima Rohmatul Laili, Wawancara Pribadi, o01, 20 Maret 2021

${ }^{22}$ Sholihatul Ummah, Wawancara Pribadi, 001, 20 Maret 2021
} 
dapat dilaksanakan secara tatap muka. Berikut pernyatakan dari Guru PAI kelas VII, yaitu Bapak Moh. Fajar Husain, S.Pd.

Pembelajaran yang digunakan pada masa pandemi COVID-19 yaitu blanded learning ada yang luring ada yang daring tidak semua peserta didik mempunyai perangkat untuk melaksanakan pembelajaran daring juga keterjangkauan sinyal internet misal di daerah pelosok atau pegunungan sering terjadi kekurangan bahkan kehilangan sinyal jadi ada beberapa peserta didik yang belum mengikuti pembelajaran secara daring, mereka yang tidak bisa melaksanakan pembelajaran secara daring dipanggil ke sekolah untuk melaksanakan pembelajaran luring dengan tetap mematuhi protokol kesehatan yang berlaku. ${ }^{23}$

Berikut pendapat guru Kelas PAI kelas VIII,

Model pengajaranyang sering dilakukan saat pandemi yaitu model daring atau dalam jaringan biasa disebut belajar online. Karena saat awal pandemi tidak memungkinkan untuk melakukan pembelajaran secara tatap muka. Alhamdulillah, beberapa bulan terakhir ini sudah bisa melakukan pembelajaran dengan tatap muka meskipun dilakukan dengan cara bergantian. Jadi pembelajaran dilakukan dengan 2 model yaitu dengan model daring dan tatap muka dalam waktu yg bersamaan dalam 1 kelas dengan cara pembagian sift 1 dan shift $2 .^{24}$

Ibu Sholihatul Ummah juga menyatakan bahwa Model pengajaranyang digunakan mengunakan media elektronik dan jaringan internet dalam aplikasi google classroom berikut keterangannya.

Kami menggunakan google classroom sebagai sarana menyampaikan tugas dan menilai hari pekerjaan peserta didik juga untuk mengetahui aktivitas belajara peserta didik dengan mengisi absensi pada google classroom. Kami menggunakan metode penugasan. ${ }^{25}$

Seluruh guru PAI di SMP Negeri 1 Ngoro melaksanakan pembelajaran PAI dengan Model E-Learning pada masa COVID-19. Mereka juga menjelaskan alasan kenapa memilih metode E-Learing sebagai model dalam pembelajaran masa darurat ini. Ibu Ima Rahmatul Laili guru PAI kelas VIII menyatakan alasanya beliau memilih model E-Learning, sebagai berikut:

Karena masa pandemi ini diharuskan pembelajaran dari rumah atau BDR. Jadi E-Learning adalah salah satu sistem pembelajaran era digital yang saat ini paling tepat digunakan. Terlebih lagi ditengah pandemi COVID19 yang tak kunjung berakhir seperti saat ini. Hampir semua lembaga pendidikan akhirnya menerapkan sistem pembelajaran jarak jauh dengan memanfaatkan teknologi guna meminimalisir risiko penularan virus corona. $^{26}$

Sependapat dengan hal itu dilain tempat guru PAI kelas VII juga mengungkapkan alasannya menggunakan model belajar E-Learning.

\footnotetext{
${ }^{23}$ Muhammad Fajar Husein, Wawancara Pribadi, 002, 21 Maret 2021

${ }^{24}$ Ima Rohmatul Laili, Wawancara Pribadi, 002, 20 Maret 2021

${ }^{25}$ Muhammad Fajar Husein, Wawancara Pribadi, o02, 20 Maret 2021

${ }^{26}$ Ima Rohmatul Laili, Wawancara Pribadi, 003, 20 Maret 2021
} 
Untuk mengurangi resiko penularan virus corona karena kalau dipaksakan dapat berdampak buruk pada guru juga peserta didik. Meskipun menggunakaan protokol kesehatan akan tetapi masih beresiko sangat besar dapat tertular atau terjangkit virus corona. Oleh karena itu digunakan model belajar E-Learning namun di negara berkembang seperti Indonesia dalam masa ini pembelajaran E-Learning masih cukup susah untuk diimplementasikan. Selain kurang terjangkau baik segi jaringan sinyal juga perangkatnya, tidak semua peserta didik mempunyai perekonomian yang mapan jadi belum bisa membeli smartphone atau laptop. Sinyal mudah ditemukan atau dijangkau pada daerah perkotaan. Sedangkan untuk daerah pedesaan masih cukup sulit didapatkan. Pembelajaran E-Learning ini diharapkan mampu mengakomodasi pembelajaran yang telah direncanakan atau mengakamodasi pembelajaran pada hari akfektif. ${ }^{27}$

Kemudian guru kelas IX menjelaskan alasanya mengapa beliau memilih pembelajaran menggunakan model E-Learing.

Karena E-Learning bisa mencakup bermacam-macam pembelajaran yang menggunakan akses internet/elektronik learning yg sesuai dengan PJJ. Denga syarat ada kuota internet yang cukup juga sinyal intenet stabil. ${ }^{28}$

Dengan berbagai alasan yang telah diungkapkan dalam wawancara dengan Pengajar PAI SMP Negeri 1 Ngoro juga menjelaskan tentang kemudahan dalam penerapan mengajaran E-Learning berikut pernyataan Ibu Sholihatu Ummah selaku guru PAI kelas IX.

Cukup mudah digunakan asal sinyal cukup ada kuota atau hotspot. Kita sudah bisa mengirim tugas melalui aplikasi google classroom. Atau membagikan link soal penilaian harian melalui google form. ${ }^{29}$

Sejalan hal itu guru PAI kelas VIII juga mengungkapan kemudahan dalam pembelajaran E learning, dalam sesi wawancara di ruang guru.

Mudah bagi yang melek teknologi tapi bisa jadi sulit bagi beberapa orang yang tidak melek teknologi. Karena ada beberapa guru ataupun peserta didik yang masih gagap teknologi (gaptek). Tp secara umum E-Learning mudah untuk diaplikasikan. ${ }^{30}$

Sependapat dengan hal itu guru kelas VII juga mengungkapkan pendapatnya dan sesi wawancara di ruang kelas.

Mudah diaplikasikan namun tetap ada yang merasa kesulitan seperti sarana pendukung dan SDM karena tidak semua guru dapat menggunakan model belajar E-Learning misal membuat model pembelajara via whatsapp, zoom, google classroom, google meet atau semacamnya. Mengaplikasikanya mudah, hanya saja yaiitu tadi masih kesulitan dalam hal device dan sinyal..$^{31}$

\footnotetext{
${ }^{27}$ Muhammad Fajar Husein, Wawancara Pribadi, 002, 21 Maret 2021

${ }^{28}$ Ibid, 003 .

${ }^{29}$ Ibid, 004 .

${ }^{30}$ Ima Rohmatul Laili, Wawancara Pribadi, 004, 20 Maret 2021

${ }^{31}$ Muhammad Fajar Husein, Wawancara Pribadi, 004, 21 Maret 2021
} 
Dari paparan data hasil wawancara tentang implementasi pembelajaran PAI dengan model E-Learning mempunyai banyak sudut pandang dan informasi yang didapatkan dapat menjadi analisi pada bab berikutnya.

\section{Inovasi Guru PAI dalam Pembelajaran E-Learning}

Terdapat beberapa inovasi yan dilakukan oleh pengajar di SMPN 1 Ngoro diantaranya menggunakan beberapa perpaduan dan sistem informasi dan aplikasi software untuk mempermudah implementasi kegiatan pembelajaran dimasa darurat Covid-19, yaitu, Google Classroom, Google Form, Hybrid Learning, dan Blended Learning

Pengajar PAI dalam implementasi model E-Learning banyak mengalami tantangan, sehingga sudah sewajarnya para pengajar membuat inovasi maupun penyesuaian dengan keadaan lingkungan belajar. Berikut paparan data dari bapak ibu guru pengajar PAI di SMPN 1 Ngoro.

Saat sesi wawancara bersama Kepala Sekolah tentang inovasi model E-Learning

Untuk sarana dan prasana dalam penunjang kegiatan pembelajaran $E$ Learning. Kami sudah mengupayakan dengan sebaik mungkin hal-hal yang berkaitan dengan proses kegiatan pembelajaran E-Learning, namun tidak dapat dikatakan sempurna karena masih progres menuju penyempurnaan. ${ }^{32}$

Kepala Urusan bidang sarana dan sarana mengungkapkan hal serupa tentang penyediaan fasilitas guna menunjang pembelajaran dengan model E-Learning.

Sudah kita fasilitasi beberapa perangkat komputer atau laboratorium komputer, server jaringan internet sekolah 10omb, sewa domain dan hosting website, akun google suite dengan penyimpanan unlimited, google classroom dan seterusnya. ${ }^{33}$ Bapak Wahyudi juga memberikan profil sekolah yang berisi tentang saran prasana penunjang pembelajaran model E-Learning. Juga klarifikasi bahwa SMPN 1 Ngoro mengunakan 2 model yaitu daring dan luring yang tertulis dalam gambar berikut:

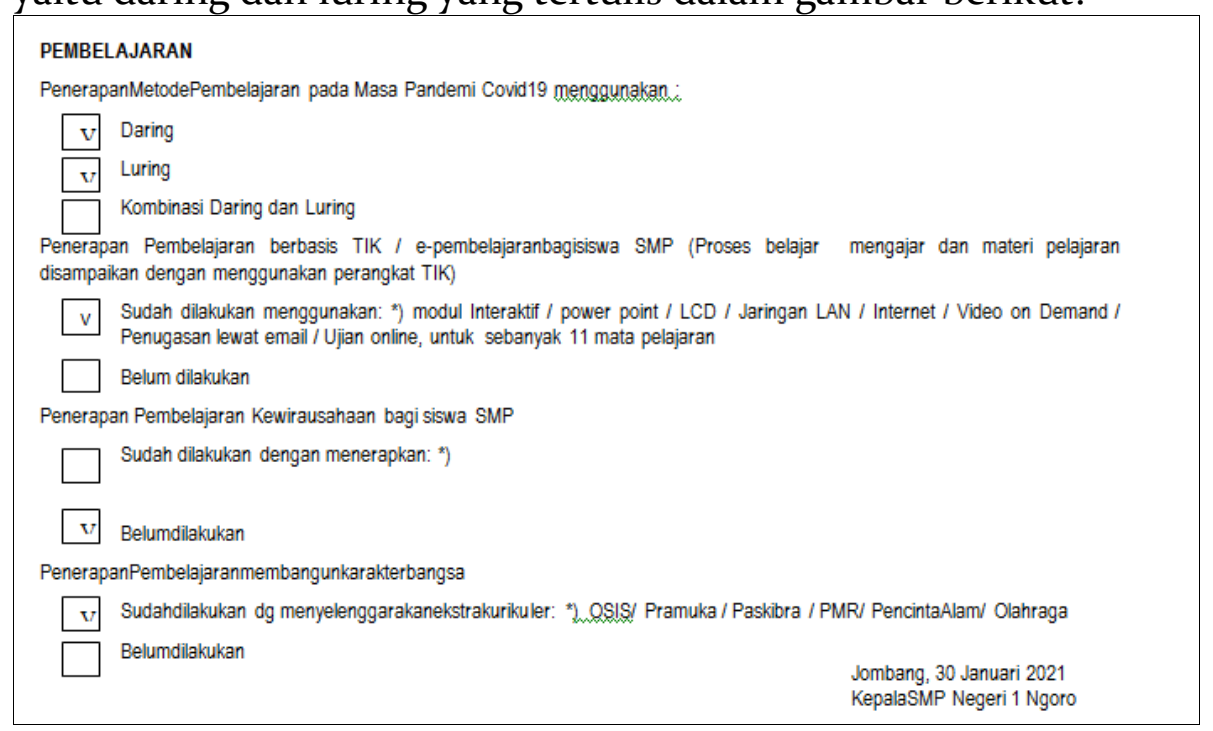

Figure 4. Pernyataan pelaksanaan E-Learning dalam profil

\footnotetext{
${ }^{32}$ Moesfajar Hadi Iswidodo, Wawancara Pribadi, 002, 17 Maret 2021

33 Wahyudi, Wawancara Pribadi, 002, 19 Maret 2021
} 
Pendapat tersebut dijelaskan lagi secara terperinci oleh waka kurikulum, hal-hal teknis berupa alur penyelesaian jika siswa mengalami kesulitan dalam pembelajaran E-Learning. Dipapar sebagai berikut:

Upaya yang dilakukan pengajar adalah dengan melakukan luring. Jadi jika memang terdapat beberapa peserta didik yang tidak dapat melaksanakan daring maka sekolah akan mendata peserta didik, dan mempetakan beberapa peserta didik tesebut. Data didapat dengan alur berawal dari guru mata pelajaran ke walikelas, dari walikelas ke BK dan dengan terpaksa maka guru mapel masing-masing memberikan soal atau materi dalam bentuk print out kemudian diberikan kepada peserta didik: 1) Peserta didik bisa datang ke sekolah 2) Guru BK mendatangi peserta didik di rumah mereka, supaya pembelajaran tetap berproses, pengajar dapat melaksanakan pembelajaran baik berupa materi ataupun penilaian kepada peserta didik. ${ }^{34}$

Dilain tempat peneliti menemui guru pengajar PAI kelas VII, beliau menjelaskan secara rinci proses penyesuaian atau inovasi yang dilaksanakan dalam pembelajaran PAI dengan model E-Learning. Inovasi dalam implementasi E-Learning yaitu interaksi dengan peserta didik menggunakan live chating atau voice note. juga video pembelajaran, bisa juga dengan respon cepat kepada peserta didik ketika pemberian tugas kemudian guru langsung memberikan pendapatnya terkait hasil pengerjaan tugas tersebut. Karena tidak semua peserta didik mampu menggunakan zoom meeting atau google meet. Jadi guru membuat video pembelajaran sekreatif mungkin untuk menjelaskan materi pembelajaran dan feed back atau imbal balik untuk peserta didik. Guru menugaskan peserta didik untuk mempraktikkannya. Namun meski ada bantuan kuota belajar dari kemendikbud ternyata untuk mengirim video masih susah tidak semua hp atau laptopnya mendukung jadi tetap masih banyak kekurangan serta kesulitan dalam pembelajaran E-Learning terutama di Indonesia yang tidak semua mampu memenuhi kebutuhan perangkat atau kurang memahami pembelajaran E-Learning juga kurang mahir menggunakan hp atau laptop untuk pembelajaran. ${ }^{35}$

Dari paparan tesebut kita dapat tafsirkan gambaran pelaksanaan inovasi guru dalam model E-Learning dengan penyesuaian sedemikian rupa supaya peserta didik mampu mengikuti pembelajaran dengan baik. walau kurang didukung oleh adanya sinyal yang stabil walau sudah memiliki bantuan kuota dari pemerintah. Selaras dengan paparan tersebut guru PAI kelas VIII juga turut memberikan penjelasannya sebagai berikut:

Agar pembelajaran tidak monoton dan tidak membuat peserta didik jenuh atau stres. Beberapa guru disarankan untuk membuat tugas di rumah dalam bentuk proyek atau memanfaatkan aplikasi pembelajaran secara daring dengan diisi konten-konten video pembelajaran yang inovatif, kreatif, bervariatif dan menarik yang dimunculkan sehingga pembelajaran dapat tersampaikan secara lebih optimal. Selain itu peran guru dan orang tua dibutuhkan dalam mendukung proses belajar di

\footnotetext{
${ }^{34}$ Anang Andik Herwanto, Wawancara Pribadi, o04, 18 Maret 2021

${ }^{35}$ Muhammad Fajar Husein, Wawancara Pribadi, oo6, 21 Maret 2021
} 
rumah dengan membangun kolaborasi demi memaksimalkan kegiatan belajar anak selama pandemi. ${ }^{36}$

Pernyataan tersebut menjelaskan bahwa guru pengajar PAI melakukan Inovasi ELearning melalui pembuatan konten-konten yang menarik baik berupa video atau project di rumah. Senada dengan hal tesebut guru kelas IX menambahkan pendapatnya, dengan cara membuat video conference, membuat PPT, membuat zoom meeting, memasukkan video pembelajaran dalam materi. ${ }^{37}$

Dari beberapa pernyataan upaya inovasi baik dari kepala sekolah, waka kurikulum, kepala urusan sarana dan prasarana, Guru PAI kelas VII, VIII dan IX. Seluruh jajaran telah mengupayakan inovasi pembelajaran dengan model E-Learning.

\section{Faktor Penghambat dan Pendukung Penerapan E-Learning}

Pada proses belajar, untuk dapat mencapai tujuan dalam belajar peserta didik sering dihadapkan pada hambatan-hambatan yang dapat mempengaruhi pelaksanaan proses belajar. Dalam kehidupan sehari-hari, hambatan sering dikenal dengan istilah halangan. Hambatan memiliki arti yang begitu penting dalam melakukan setiap kegiatan. Hambatan dapat menyebabkan pelaksanaan suatu kegiatan menjadi terganggu. Menurut Oemar, Hambatan adalah segala sesuatu yang menghalangi, merintangi, menghambat yang ditemui manusia atau individu dalam kehidupannya sehari-hari yang datangnya silih berganti, sehingga menimbulkan hambatan bagi individu yang menjalaninya untuk mencapai tujuan.

Semua literatur mengindikasikan bahwa tidak semua peserta didik akan sukses dalam pembelajaran online, hal itu disebabkan karena perbedaan faktor lingkungan belajar dan karakteristik peserta didik $^{38}$ Anugrahana menyatakan dalam risetnya bahwa ada 3 hambatan yang ditemukan dalam pembelajaran daring, yaitu: kondisi orang tua siswa yang lebih banyak menggunakan aplikasi WhatsApps (WA), kesulitan mencari jaringan internet dan gawai telepon pintar yang lebih sering dibawa orang tua yang bekerja, dan paling klasik, kesulitan sinyal. ${ }^{39}$

Amelia juga melakukan penelitian mengelompokan beberapa hambatan siswa ketika pengajaran daring berlangsung adalah, kuota internet yang tidak memadai atau terbatas, koneksi internet yang tidak stabil, adanya distraksi di lingkungan rumah (berisik, sering disuruh-suruh), kapasitas gawai tidak memadai untuk memasang aplikasi penunjang pembelajaran daring dan penyimpanan file mata pelajaran, sulit dalam memahami materi pembelajaran, serta sulit berkomunikasi secara langsung dengan teman-teman di kelas. ${ }^{40}$

Pada penelitian ini, penulis menemukan sebuah temuan dimana masyarakat di kawasan Jombang merasa kurang maksimal dalam belajar daring. Bahkan, beberapa pihak dari mereka merasa tidak setuju dengan adanya pembelajaran ini. Hal ini

\footnotetext{
${ }^{36}$ Ima Rohmatul Laili, Wawancara Pribadi, oo6, 20 Maret 2021

${ }^{37}$ Muhammad Fajar Husein, Wawancara Pribadi, oo6, 20 Maret 2021

${ }^{38}$ Nakayama, M., Mutsuura, K., \& Yamamoto, H. (2014). Impact of learner's characteristics and learning behaviour on learning performance during a fully online course. Electronic Journal of E-Learning, 12(4), 394-408

${ }^{39}$ Andri Anugrahana, "Hambatan, Solusi dan Harapan: Pembelajaran Daring Selama Masa Pandemi Covid-19 Oleh Guru Sekolah Dasar," Scholaria: Jurnal Pendidikan dan Kebudayaan 10, no. 3 (28 September 2020): 282-89, https://doi.org/10.24246/j.js.2020.v1o.i3.p282-289.

${ }^{40}$ Huzaimah dan Amelia, "Hambatan yang Dialami Siswa Dalam Pembelajaran Daring Matematika Pada Masa Pandemi COVID-19."539
} 
dikarenakan banyaknya kendala yang dirasakan oleh masyarakat di sana. Berdasarkan wawancara yang dilakukan pada informan, yakni orangtua, pelajar, dan guru.

Pertama, yaitu kendala dari peserta didik/murid. Selama pemberlakuan belajar online atau PJJ, banyak peserta didik yang merasa proses belajarnya tidak efektif. kebanyakan dari mereka mengatakan bahwa PJJ membuat pelajaran jadi lebih sulit dipahami. Ditambah dengan kesulitan dalam mengakses jaringan, tidak memiliki sarana yang memadai untuk belajar online, hingga rasa bosan. Bahkan, beberapa kasus menyebutkan bahwa proses belajar di masa pandemi secara daring, membuat tingkat semangat belajar jadi turun. Hal tersebut pun sesuai dengan yang diungkapkan oleh anggota Komisi D DPRD Jombang, Mustofa kepada Radar Jombang (2020), dimana semua pihak sedang mencari solusi untuk melanjutkan proses belajar mengajar yang lebih efektif. Pasalnya, pihak mereka pun menilai bahwa anak-anak di daerahnya merasa kesulitan ketika belajar secara online.

Kendala juga datang dari wali murid/orangtua. Biasanya pihak orang tua hanya mengawasi proses belajar saat anakanaknya mengerjakan PR atau mengulang pelajaran. Selama pandemi, mereka dipaksa untuk selalu ikut belajar dengan anakanaknya. Terlebih bagi para orangtua siswa sekolah dasar yang hampir seluruhnya mengerjakan setiap tugas anak-anaknya. Ada juga yang merasa geram, sebab pembelajaran dilakukan daring, para orangtua yang kelimpungan, namun harus dibebankan dengan biaya-biaya sekolah. Misalnya saja biaya SPP atau administrasi bulanan. Ditambah dengan kurangnya kemampuan digital orangtua, terlebih yang sudah usia lanjut sehingga sulit sekali membantu anak anaknya ketika belajar di rumah.

Sementara itu, kendala yang dialami oleh beberapa guru di Jombang, bukan hal mudah untuk beradaptasi dengan konsep pembelajaran yang berbeda dari biasanya. Menyiapkan materi pelajaran, menyiapkan soal-soal, hingga sarana pendukung proses belajar. Dari mulai membuat materi yang relevan, proses share ke media online, memenuhi ruang aplikasi pesannya dengan grup siswa, dirumitkan dengan segala pertanyaan orangtua dan siswa. Meskipun pihak kementrian sudah memberikan modul untuk membantu proses pembelajaran daring, namun tidak semua guru bisa mengaksesnya dengan mudah.

Namun, di balik faktor penghambat, tentu ada faktor pendukung. Setidaknya ada tiga faktor yang bisa kita jadikan pegangan atau bahan renungan sebelum kita menerapkan E-Learning. Faktor pertama adalah sumber daya manusia (SDM), kedua sarana dan prasarana, dan yang ketiga implementasinya. Ketiga faktor inilah yang akan menentukan berhasil tidaknya E-Learning diterapkan.

Dalam kasus SMPN 1 Ngoro Jombang, Kepala sekolah mengklarifikasi bahwa mendukung penyelenggaraan pembelajaran dengan model E-Learning diantaranya akan terus melengkapi baik sarana dan sarana yang berkaitan dengan E-Learning, sudah tersedia 3 ruang laboratorium komputer dengan 3 server yang biasa digunkan untuk ujian sekolah berbasis komputer, namun hal itu dirasa belum mencukupi untuk kebutuhan E-Learning secara keseluruhan. E-Learning juga masih dirasa awam bagi peserta didik jadi hal-hal yang berkaitan dengan E-Learning masih butuh 
beberapa penyempurnaan. Berikut klarifikasi beliau tentang dukungan pembelajaran E-Learning.

Karena ini termasuk hal baru kemudian sarana, prasana dan fasilitas masih kita upayakan bisa menjangkau seluruh peserta didik. disisi lain tidak semuanya peserta didik memiliki sarana yang memadai jadi ke depan tetap penyempurnaan harus dilaksanakan baik dari pihak sekolah PTK maupun peserta didik sehingga pembelajaran sesuai dengan tujuan atau yang diharapkan khususnya pada kurikulum darurat masa COVID-19. Sudah seharusnya proses pembelajaran itu, ada pertemuan antara guru dan peserta didik jadi pembimbingan dan pendampingan peserta didik itu harus terus diperhatikan karena peserta didik masih dalam pertumbuhan remaja, dan pelajar SMP masih sangat perlu pendampingan. Beda lagi kalu sudah SMA atau Mahasiswa mereka sudah mampu belajar secara mandiri, sudah hampir 2 tahun model pengajaran E-Learning belum bisa maksimal yaitu tadi kendala yang beraneka ragam, baik dari sarana dan prasarana sekolah. maupun peserta didik. Kemudian kesadaran peserta didik utamanya untuk mengikuti pembelajaran E-Learning atau daring atau online karena pengetahuan itu sangat dibutuhkan dalam kehidupan kita. ${ }^{41}$

Ditegaskan lagi oleh kepala urusan saran dan prasana terkait dukunganya untuk menjadikan pembelajaran denganmodel E-Learningdapat berjalan sesuai apa yang menjadi tujuannya di antaranya peningkatan ketrampilan guru dan melengkapi sarana dan prasarana dalam pelaksanaan E-Learning berikut pernyataan beliau terkait dukungan tesebut.

Senantiansa mengembangkan kompetensi guru, mengikut sertakan guru dalam pelatihan E-Learning, kemudian melengkapi kebutuhan bapak ibu guru pada umumnya guna melaksanakan $E$ Learning dengan sebaik-baiknya. ${ }^{42}$

Table 1 Fasilitas sarana komputer sekolah

\begin{tabular}{|c|l|c|c|c|c|c|}
\hline \multirow{2}{*}{ No } & \multirow{2}{*}{$\begin{array}{c}\text { Nama Alat } \\
\text { Praktek }\end{array}$} & \multicolumn{3}{|c|}{ Kondisi Saat Ini } & \multicolumn{2}{c|}{$\begin{array}{c}\text { Kebutuha } \\
\text { J Alat }\end{array}$} \\
\cline { 3 - 7 } & $\begin{array}{c}\text { lah } \\
\text { Alat }\end{array}$ & $\begin{array}{c}\text { Jumla } \\
\text { haik / } \\
\text { Berfu } \\
\text { ngsi }\end{array}$ & $\begin{array}{c}\text { Jumlah } \\
\text { Rusak / } \\
\text { Tidak } \\
\text { Berfungs } \\
\text { i }\end{array}$ & $\begin{array}{c}\text { Jum } \\
\text { lah } \\
\text { Alat }\end{array}$ & $+/-$ \\
\hline A & $\begin{array}{l}\text { AlatPrakte } \\
\text { k }\end{array}$ & & & & & \\
\hline 1. & $\begin{array}{l}\text { Komputer } \\
\text { Laptop }\end{array}$ & 22 & $\mathbf{2 2}$ & - & 44 & -22 \\
\hline 2. & $\begin{array}{l}\text { Komputer } \\
\text { PC }\end{array}$ & 68 & 60 & 8 & 821 & -753 \\
\hline 3. & $\begin{array}{l}\text { Komputer } \\
\text { Server }\end{array}$ & 4 & - & - & - & - \\
\hline
\end{tabular}

\footnotetext{
${ }^{41}$ Moesfajar Hadi Iswidodo, Wawancara Pribadi, 005, 17 Maret 2021

$4^{2}$ Wahyudi, Wawancara Pribadi, 004, 19 Maret 2021
} 


\begin{tabular}{|c|l|c|c|c|c|c|}
\hline 4. & LCD & 2 & 1 & 1 & 30 & -28 \\
\hline 5. & $\begin{array}{l}\text { Tape } \\
\text { Audio }\end{array}$ & - & - & - & 2 & -2 \\
\hline 6. & TV & - & - & - & 4 & -4 \\
\hline 7. & Handycam & - & - & - & 2 & -2 \\
\hline 8. & Printer & 3 & - & - & 10 & -7 \\
\hline
\end{tabular}

Sumber dokumentasi sekolah tahun 2021

Setiap model mempunyai kesesuain dengan materi ajar atau kondisi tertentu, maka kemungkinan terdapat beberapa faktor-faktor penting yang mempengaruhi selain faktor pendukung tentunya faktor penghambat. Dalam sesi wawancara dengan kepala sekolah, beliau menyampaikan bahwa masih terjadi beberapa hambatan yang terjadi sehingga pembelajaran kurang maksimal atau ideal karena dilaksanakan pada masa darurat COVID-19 jadi kemungkinan terjadi ketidak siapan baik berupa sarana dan prasana juga sumber daya manusia (SDM). berikut penjelasan beliau:

Terjadi beberapa hambatan dalam pembelajaran model $E$ Learning yaitu diantaranya tindak lanjut atau evaluasi setelah pembelajaran E-Learning dari guru. Yang seharusnya setiap selesai pembelajran diadakan evaluasi mungkin dikarenakan masa COVID-19 ini cukup berpengaruh juga terhadap pembelajaran daring. ${ }^{43}$

Hal serupa dinyatakan juga oleh wakil kepala kurikulum. Sekolah berupaya untuk menyempurnakan sarana dan prasarana namun tetap ada beberapa hambatan yang belum mampu dicarikan solusi yaitu jaringan internet. Berikut pemaparan beliau: Tidak terjangkau jaringan internet, smartphone yang tidak sesuai spesifikasinya dan kuota internet yang mencukupi juga kemandirian peserta didik, itulah beberapa hambatan dalam pembelajaran E-Learning. ${ }^{44}$

Selaras dengan hal tersebut kepala urusan sarana dan prasarana beliau menambahkan faktor penghambat yaitu media yang kurang memadai karena tidak semua peserta didik mempunyai kesejahteraan ekonomi yang cukup sehingga belum mampu membeli smartphone/ gawai sebagai sarana melaksanakan E-Learning dengan baik. Dan berdampak pada guru yang membutuh pekerjaan ekstra karena harus mencari dan memberikan tugas belajar kepada beberapa peserta didikyang belum melakasanakan pembelajaran secara E-Learning.

Hambatannya yaitu tidak semua peserta didik mampu menggunakan perangkat IT sesuai harapan sekolah, sehingga guru memiliki pekerjaan ekstra karena peserta didik ada yang tidak aktif mengikuti pembelajaranE-Learning. maka guru harus mencari dan memberikan solusi penyelesaian sedemikian hingga peserta didik dapat mengikuti pembelajaran dengan baik. ${ }^{45}$

Kemudian peneliti berapa kepada informan guru PAI kelas VII, memaparkan tentang faktor penghambat yang hampir sama dengan paparan data dari waka kurikulum

\footnotetext{
${ }^{43}$ Moesfajar Hadi Iswidodo, Wawancara Pribadi, 003, 17 Maret 2021

${ }^{44}$ Anang Andik Herwanto, Wawancara Pribadi, 003, 18 Maret 2021

45 Wahyudi, Wawancara Pribadi, 003, 19 Maret 2021
} 
juga kaur sarana dan prasarana yaitu jaringan internet juga gawai/smartphone yang mendukung. Ditambahkan lagi belum adanya standar penerapan E-Learning yang pakem. Model baku yang bisa digunakan oleh para guru karenaguru juga merasa bahwa masih awam dalam model E-Learning. jadi dapat diartikan para guru masih dalam tahap ujicoba dalam pelaksanaannya. Berikut hasil wawancara dengan beliau: Kesulitan dalam implementasi model E-Learning cukup banyak diantaranya: 1) Tidak semua peserta didik mempunyai device atau perangkat untuk E-Learning, 2) Pembelajaran cenderung monoton tidak semua guru dapat kreatif membuat media pembelajaran yang menarik, juga kurangnya kreativitas dalam proses pembelajaran karena dalam pelaksanaanya, hanya meniru rancang pembelajaran orang lain atau sesuai buku peserta didik by literatur. Jadi tidak ada tatap muka. selain itu masih belum ada pembelajaran E-Learning yang pakem atau standart dalam implementasinya atau mayoritas pengajar masih menerka dan meraba-raba bagaimana keefektifannya, selain itu guru tidak bisa mengawasi peserta didik secara langsung. ${ }^{46}$

Menambahkan paparan dari guru kelas VII, guru kelas 8 juga berpendapat serupa namun ada tambaha lagi tentang metode yang digunakan kurang variatif atau monoton dan model E-Learning yang belum melibatkan interaksi aktif atau tebatas pada penugas saja. Berikut ada 8 hambatan / kendala yang dialami dalam penerapan model E-Learning.

Adapun kendala dalam pembelajaran daring seperti: (1) Lokasi rumah tidak terjangkau jaringan internet, termasuk kuota internet murid minimalis, (2) Media pembelajaran yang digunakan para guru dominan monoton dan membuat para murid merasa jenuh atau bosan. Kemudian, (3) Pembelajaran dominan belum interaktif, (4) Karakter ataupun perilaku para murid sulit dipantau, (5) Pembelajarannya cenderung tugas online, (6) Tugas diberikan para murid menumpuk (7) Penyerapan materi pelajaran sangat minimalis, dan (8) Penilaian yang dilakukan guru berupa Penilaian Harian (PH), Penilaian Tengah Semester (PTS), Penilaian Akhir Semester (PAS), termasuk Ujian Sekolah (US) kurang berintegritas. ${ }^{47}$

Senada dengan hal tersebut beberapa peserta didik juga menyampaikan bahwa guru kurang berinteraksi kepada murid. Berikut hasil wawancara dengan Octa Puteri Maharani kelas VII.

Perbanyak interaksi kepada peserta didik, karena peserta didik dalam beberapa materi masih merasa kebingungan dankurang memahami isi materi yang diajarkan muri" 48

\section{Simpulan}

\footnotetext{
${ }^{46}$ Muhammad Fajar Husein, Wawancara Pribadi, 002, 21 Maret 2021

${ }^{47}$ Ima Rohmatul Laili, Wawancara Pribadi, 005, 20 Maret 2021

${ }^{48}$ Oktavia Putri Marliana, Wawancara Pribadi, 004, 25 Maret 2021
} 
Berdasarkan pada analisis data hasil penelitian serta sumber rujukan yang telah diolah, maka dapat diambil beberapa kesimpulan. Pertama, pengajaran PAI dengan model E-Learning menggunakan fasilitas Google Suite dengan menggunakan fiturfitur yang ada di dalamnya seperti Google classroom, Google Form, Google Meet dan lainya. Berdasarkan aktifitas pembelajaran yang ada dalam model E-Learning merupakan kategori E-Learning yang bersifat dinamis karena bisa menghadirkan suasana pembelajaran seperti pembelajaran tatap muka di kelas.

Inovasi pengajaran guru PAI dalam model E-Learning bisa dilaksanakan secara langsung (synchronous) yaitu melalui modul chat dan dilaksanakan secara tidak langsung (asynchronous) melalui modul bacaan, kuis, tugas, dan forum. Hambatan yang dihadapi oleh user E-Learning (guru dan siswa) dalam proses mengimplementasikan E-Learning PAI dibagi menjadi 2, hambatan untuk guru dan peserta didik. Untuk hambatan yang dihadapi guru PAI dalam implementasi $E$ Learning PAI meliputi, (1) kurangnya keterampilan/skill menggunakan E-Learning, (2) koneksi internet di luar lingkungan sekolah, (3) kebutuhan PAI akan E-Learning, (4) persepsi guru terhadap E-Learning, dan (5) otivasi guru PAI untuk menggunakan E-Learning.

Sementara untuk hambatan yang dialami peserta didik dalam menggunakan $E$ Learning antara lain; (1) kurangnya kemandirian peserta didik dalam pembelajaran E-Learning, (2) koneksi internet di luar lingkungan sekolah, (3) kurangnya ketersediaan gawai yang ideal dalam E-Learning.

Adapun faktor pendukung implementasi E-Learning di SMP adalah terpenuhinya infrastruktur E-Learning: Infrastruktur E-Learning dapat berupa personal computer (PC), jaringan komputer, internet dan perlengkapan multimedia, sistem dan aplikasi E-Learning: Sistem perangkat lunak yang mem-virtualisasi proses belajar mengajar konvensional, serta konten E-Learning: Konten dan bahan ajar yang ada pada ELearning system (Learning Management System).

Berangkat dari situ, penulis mempunya beberapa saran. Pertama, saran untuk kepala sekolah, yaitu seharusnya melakukan pengadaan training E-Learning bagi guru khususnya guru PAI lebih diefektifkan lagi. Dalam satu kali pelatihan mungkin bisa diberikan satu materi secara mendalam. Misalkan pada tahun ajaran 2021-2022 dilaksanakan training pembuatan video pembelajaran. Apabila guru mengalami kesulitan dalam menggunakan E-Learning, maka sekolah bisa menyediakan fasilitator yang bisa dijadikan tempat konsultasi bagi guru. Sekolah bisa memperhatikan perkembangan guru setelah mengikuti training dan mendorong guru untuk mengaktifkan E-Learning pada mata pelajaran masing-masing. Setidaknya ada update materi di semua mata pelajaran sehingga bisa mempermudah siswa dalam belajar.

Kedua, saran untuk guru, dalam menggunakan dan memanfaatkan teknologi seperti E-Learning tidak perlu takut dan ragu untuk mencoba. Dengan mencoba akan menjadi sebuah pengalaman belajar yang berharga sehingga lama kelamaan ketrampilan menggunakan E-Learning akan menjadi lebih lancar dengan sendirinya. Penggunaan E-Learning sebenarnya sangat bermanfaat untuk pemberian materi dan evaluasi. Materi PAI juga mencakup pengetahuan (kognitif) yang harus dipahami oleh siswa sebelum mereka bisa mempraktikan dalam kehidupan sehari-hari. 
Sedangkan waktu pelajaran PAI sangat terbatas, sehingga E-Learning dapat membantu dalam penyampaian materi PAI serta proses evaluasinya.

Sementara itu, saran terakhir untuk siswa Siswa sebaiknya lebih aktif mencari bahan materi yang ada di E-Learning ataupun di sumber lainnya dan tidak hanya mengandalkan pengetahuan dari Buku siswa atau pembelajaran di kelas.

\section{DAFTAR PUSTAKA}

Abusiri. "Implementasi E-Learning Dalam Upaya Meningkatkan Kreativitas Dosen Dan Mahasiswa Di Stai Alhikmah Jakarta." Hikmah Xv (2019).

Anugrahana, Andri. "Hambatan, Solusi dan Harapan: Pembelajaran Daring Selama

Masa Pandemi Covid-19 Oleh Guru Sekolah Dasar.” Scholaria: Jurnal

Pendidikan dan Kebudayaan 10, no. 3 (28 September 2020): 282-89. https://doi.org/10.24246/j.js.2020.v10.i3.p282-289.

Bruce Joyce. Models of Teaching edisi 8 : Model-Model Pengajaran. 8 ed. Yogyakarta: Pustaka Pelajar, 2016.

Clark, Ruth Colvin, dan Richard E Mayer. E-Learning and the Science of Instruction. United States of America: Pfeiffer, 2011.

Dashraath, Pradip, Jing Lin Jeslyn Wong, Mei Xian Karen Lim, Li Min Lim, Sarah Li, Arijit Biswas, Mahesh Choolani, Citra Mattar, dan Lin Lin Su. "Coronavirus Disease 2019 (COVID-19) Pandemic and Pregnancy." American Journal of Obstetrics and Gynecology 222, no. 6 (Juni 2020): 521-31. https://doi.org/10.1016/j.ajog.2020.03.021.

Fahmi, Muhammad Hanif. "Komunikasi Synchronous Dan Asynchronous Dalam ELearning Pada Masa Pandemic Covid-19.” Jurnal Nomosleca 6, no. 2 (30 Oktober 2020). https://doi.org/10.26905/nomosleca.v6i2.4947.

Hanum, Fauziah, dan Heylen Amildha Yanuarita. "Efektivitas Pembelajaran Dalam Jaringan (Daring) Selama Pandemi Covid-19 Di Kabupaten Jombang" 4, no. 4 (2020): 6.

Herwanto, Anang Andik. Selaku Wakil Kepala Sekolah Bidang Kurikulum SMPN 1 Ngoro Jombang. Mengenai Kurikulum Sebagai Wawancara. 18 Maret 2021.

Husain, Muhammad Fajar. Selaku Guru PAI SMPN 1 Ngoro Jombang. Mengenai Pembelajaran PAI dengan sistem E-Learning Sebagai Wawancara. 21 Maret 2021.

Huzaimah, Pipip Zulfa, dan Risma Amelia. "Hambatan yang Dialami Siswa Dalam Pembelajaran Daring Matematika Pada Masa Pandemi COVID-19." Jurnal Pendidikan Matematika 05, no. o1 (2021): 9.

Iswidodo, Moesfajar Hadi. Selaku Kepala Sekolah SMPN 1 Ngoro Jombang Mengenai Penerapan Pembelajaran E-Learning sebagai Wawancara Pribadi. 17 Maret 2021.

Laili, Ima Rohmatul. Selaku Guru PAI SMPN 1 Ngoro Jombang. Mengenai Pembelajaran PAI dengan sistem E-Learning Sebagai Wawancara. 20 Maret 2021

Lidia Simanihuruk, Janner Simarmata, Acai Sudirman, M. Said Hasibuan, Meilani Safitri, Oris Krianto Sulaiman, Rahmi Ramadhani, dan Syafrida Hafni Sahir. 
E-Learning: Implementasi, Strategi dan Inovasinya. 1 ed. Medan: Yayasan Kita Menulis, 2019.

Marliana, Oktavia Putri. Selaku Siswi SMPN 1 Ngoro Jombang. Mengenai Tanggapan Peserta Didik terhadap E-Learning sebagai Wawancara. 25 Maret 2021Mayadas, Frank. "Asynchronous Learning Networks: A Sloan Foundation Perspective.” Online Learning 1, no. 1 (19 Maret 2019). https://doi.org/10.24059/olj.vii1.1941.

Merriam. Qualitative Reseach and Case Study, Aplication in Education. San Fransisco: John Wiley \& Sons, 1998.

Nurul, Ulfatin. Metode Penelitian Kualitatif di Bidang Pendididkan: Teori dan Aplikasinya. Malang: Madia Nusantara Creative, 2015.

Prawiradilaga, Dewi Salma. Mozaik Teknologi Pendidikan: E-Learning. Kencana, 2016. Qualification and Curriculum Authority/QCA. Assessment for Learning: Using Assessment to Raise Achievement in Mathemathics. London: Great Britain, 2003.

Rusman., Kurniawan, D., \& Riyana, C. Pembelajaran berbasis teknologi informasi dan komunikasi, mengembangkan profesionalitas guru. Jakarta: PT. Raja Grafindo, 2011.

Sadikin, Ali, dan Afreni Hamidah. "Pembelajaran Daring di Tengah Wabah Covid19." BIODIK 6, no. 2 (30 Juni 2020): 109-19. https://doi.org/10.22437/bio.v6i2.9759.

Sugiyono. Metode Penelitian Pendidikan Pendekataan Kuantitatif, Kualiatatif, dan RED,. Bandung: Alfabeta, 2016.

Sukandarrumidi. Metodologi Penelitian. Yogyakarta: Gadjah Mada UniversityPress, 2004 .

"Surat Edaran Gubernur Jawa Timur Tanggal 15 Maret 2020 Perihal Peningkatan Kewaspadaan Corona Virus Disease 2019 (Covid-19) - Universitas Islam Negeri Sunan Ampel Surabaya.” Diakses 1 Juni 2021. https://w3.uinsby.ac.id/surat-edaran-gubernur-jawa-timur-tanggal-15maret-2020-perihal-peningkatan-kewaspadaan-corona-virus-disease-2019covid-19/.

Ummah, Sholihatul. Selaku Guru PAI SMPN 1 Ngoro Jombang. Mengenai Pembelajaran PAI dengan sistem E-Learning Sebagai Wawancara. 20 Maret 2021

Wahyudi. Selaku Wakil Kepaka Sekolah Bidang Sarana Prasarana SMPN 1 Ngoro Jombang. Mengenai Kesiapan Sarpras dalam Menghadapi E-Learning Sebagai Wawancara. 19 Maret 2021

Yulianto, Subakdo Eko. "Pengaruh Persepsi Kemudahan Dan Persepsi Kemanfaatan Terhadap Pemanfaatan E-Learning Dengan Model Tam Di Smk Muhammadiyah 3 Yogyakarta," t.t., 18.

Zemke, R. . “. (2002) Who Need Learning Theory anyway? , 39(9), 86-88.” Training Magazine, 2002, 39 edisi. 